\title{
EVALUASI KOMPLIKASI PLATE EXPOSURE PASCA-RESEKSI AMELOBL ASTOMA MANDIBULA DENGAN REKONSTRUKSI PELAT TITANIUM DI RSUP DR. SARDJITO YOGYAKARTA
}

\author{
Maria Goreti Widiastuti \\ Staf Medik Bedah Mulut RSUP Dr. Sardjito \\ Email: mariagoretiwidiastuti@gmail.com \\ Marsetyawan HNE Soesatyo \\ Bagian Histologi Fakultas Kedokteran Universitas Gadjah Mada
}

Rahardyan Magetsari

Staf Medis Ortopedi dan Traumatologi RSUP Dr. Sadjito

Alva Edy Tontowi

Departemen Teknik Mesin dan Industri Fakultas Teknik Universitas Gadjah Mada

\begin{abstract}
Resection of the jaw is a primary option of treatment in mandibular ameloblastoma with bone damage. Mandibular resection will cause mandibular stability disturbance due toloss of some part of the bone. Instability of the mandible can cause aesthetic, physiological, and psychological malfunctioning. To restore its stability, installment of mandibular reconstruction plate on the remaining mandibular by using screws. However, it is not uncommon that plate exposure occurs following mandibular reconstruction, caused by inaccurate adaptation of the plates to the mandibular bone. A 3D stereolithography modelcan help provide the best assesment on the bone defect, plan the making of the more easily pre-operative curved plates and provide more accurate faster surgery time. Objective: To evaluate plate exposure after mandibular resection with titanium reconstruction plates in Dr. Sardjito Hospital. Case report: A case was reported on mandibular reconstruction after resection of ameloblastoma with titanium plate performed in Dr. Sardjito Hospital that experienced intra-oral plate exposure and oro-cutaneous fistula on the left mandible. The clinical evaluation showed the curved titanium plate did not adapt well with the remaining mandibular bone; therefore, the titanium plate was removed without replacing it with a new plate. Inappropriate adaptationof curved titanium plate is one of the main causes of plate exposure. The use of a 3D stereolithography model is very helpful for the success of mandibular reconstruction.
\end{abstract}

Keywords: Mandibular resection; Plate exposure; Reconstruction.

\begin{abstract}
ABSTRAK
Reseksi rahang merupakan perawatan pilihan yang utama pada ameloblastoma mandibula dengan kerusakan tulang yang luas.Tindakan reseksi pada mandibula akan menyebabkan gangguan stabilitas pada mandibula akibat adanya bagian tulang yang hilang. Ketidakstabilan mandibula menimbulkan gangguan fungsi estetis, fisiologis, dan psikologis. Untuk mengembalikan stabilitas mandibula diperlukan pemasangan pelat rekonstruksi mandibula pada tulang mandibula yang tersisa dengan menggunakan sekrup. Akan tetapi tidak jarang didapatkan adanya komplikasi plate exposure setelah tindakan rekonstruksi mandibula, karena adaptasi pelat terhadap tulang mandibula kurang akurat. Model stereolitografi 3 dimensi dapat membantu memberikan penilaian terhadap defek tulang yang paling baik, merencanakan pembuatan lengkung pelat pre-operatif lebih mudah dan lebih akurat dan mempercepat waktu operasi Tujuan: untuk mengevaluasi komplikasi plate exposure pasca-reseksi mandibula setelah rekonstruksi pelat titanium di RSUP Dr. Sardjito. Laporan Kasus: Dilaporkan sebuah kasus rekonstruksi mandibula pasca reseksi ameloblastoma dengan pelat titanium yang dilakukan di RSUP Dr. Sardjito dan mengalami komplikasi plate exposure intra oral dan fistula oro kutan pada
\end{abstract}


mandibula sinistra. Evaluasi klinis menunjukkan lengkung pelat titanium tidak beradapatasi dengan baik terhadap bagian tulang mandibula yang tersisa, sehingga dilakukan pelepasan pelat titanium tanpa diganti pelat yang baru. Adaptasi lengkung pelat titanium yang kurang sesuai merupakan salah satu penyebab utama terjadinya komplikasi plate exposure. Penggunaan model stereolitografi 3 dimensi sangat membantu keberhasilan rekonstruksi mandibula

\section{Kata Kunci: Plate Exposure; Rekonstruksi; Reseksi rahang.}

\section{PENGANTAR}

Ameloblastoma adalah tumor jinak odontogenik yang paling sering terjadi pada rahang, diperkirakan jumlahnya $1 \%$ dari tumor dan kista rongga mulut (Gardner, 1996). Bangsa Amerika berkulit hitam dan penduduk Afrika Barat jauh lebih sering menderita ameloblastoma dan diketahui jumlahnya $6 \%$ atau lebih banyak dari tumor rongga mulut (Soames, 1998). Ameloblastoma tumbuh lambat, tetapi bersifat agresif dan destruktif dengan kemampuan mencapai ukuran yang luas, dapat mengikis tulang dan menginvasi jaringan di sekitarnya (Gunggum dan Hosrogen, 2005; Chen dkk., 2000).

Tempat terjadinya ameloblastoma lebih sering pada mandibula dibandingkan dengan maksila. Sembilan puluh limakoma delapan persen ameloblastoma terjadi pada mandibula, dengan lokasi paling banyak di korpus mandibula $(60,6 \%)$,sedang pada maksila hanya $4,2 \%$ (Kim, 2001).Hasil penelitian yang dilakukan di RSUP Cipto Mangunkusumo Jakarta pada tahun 2011 menunjukkan bahwa 97,14\% kasus ameloblastoma terjadi di mandibula, dan angka kejadian pada daerah ramus mandibula sebesar 54,41\% (Yulvie dkk., 2011).

Menurut DuBrull (1988), mandibula merupakan bagian tulang kepala yang membentuk sepertiga wajah bagian bawah dan tempat perlekatan otot-otot lidah dan otototot pengunyahan, sehingga mandibula mempunyai peranan penting dalam fungsi pengunyahan dan fonetik, mendukung gigi-gigi dan estetik (Oliveira, 2013). Reseksi rahang merupakan perawatan pilihan yang utama pada ameloblastoma mandibula dengan kerusakan tulang yang luas, sesuai dengan hasil penelitian Rana (2011)yang menunjukkan bahwa tindakan reseksi mandibula akibat tumor, paling banyak disebabkan oleh ameloblastoma.

Hilangnya sebagian tulang mandibula akibat reseksi menyebabkan terjadinya gangguan fungsi estetis dan fisiologis, yang meliputi gangguan fungsi mastikasi, artikulasi, menelan, dan pernapasan (Chen dkk., 2000; Oji dkk., 2003; Atilgan dkk., 2010; Rana dkk.,2011; Boyd dkk., 2012). Gangguan fungsi mandibula bervariasi dari gangguan yang ringan sampai berat, berupa deviasi mandibula ke arah sisi yang direseksi karena tidak adanya perlawanan terhadap tarikan otot mastikasi yang masih ada, kontraktur jaringan lunak dan pembentukkan skar. Keterbatasan gerakan rahang, maloklusi dan masalah-masalah propriosepsi juga sering terjadi (Clement dkk., 1997).Hilangnya dukungan terhadap otot-otot suprahioid dapat menyebabkan reduksi jalan nafas (Oliveira, 2013).

Gangguan fungsi estetis dan gangguan fungsional yang berat akan menurunkan kualitas hidup pasien, sehingga harus dilakukan rekonstruksi pascareseksi mandibula (Oliveira, 2013; Pawlowska, 2013). Pelat rekonstruksi mandibula dan sekrup merupakan alat aloplastik yang paling banyak digunakan untuk rekonstruksi mandibula (Clement dkk., 1997; Maurer, 2010).Logam yang paling banyak digunakan untuk pembuatan pelat-pelat ini adalah stainless steel, vitalium dan titanium. Pelat rekonstruksi stainless steel dan titanium telah dikembangkan dalam usaha untuk mendapatkan pilihan rekonstruktif mandibula yang cepat, single-staged, dan terpercaya dalam mempertahankan fungsi dan bentuk rongga mulut, tetapi penggunaan pelat rekonstruksi ini menunjukan derajat keberhasilan yang berbeda (Clement dkk., 1997).

Pengembangan Titanium Hollow Osteointegrated Reconstruction Plate (THORP) merupakan usaha untuk mengatasi kegagalan dari sistem pelat yang lebih dulu digunakan.THORP merupakan sistem fiksasi mandibula pertama kali mempunyai perangkat keras yang lebih stabil karena adanya osteointegrasi antara sekrup dan tulang serta adanya mekanisme penguncian 
pada tulang kepala sekrup pada lubang sekrup pelat (Blackwell dan Lacombe,1999). Menurut Clement dkk.(1997) adanya lubang sekrup pada pelat titanium dan dengan membuat lubang kecil sepanjang badan sekrup akan memberikan pertumbuhan tulang kedalam sekrup sehingga meningkatkan stabilitas pelat ketika sekrup dan tulang menyatu.

Pemilihan sistem pelat titanium yang paling cocok sangat penting dalam menunjang keberhasilan tindakan rekontruksi. Defek mandibula akibat hilangnya tulang membutuhkan sistem yang lebih kuat (load bearing) untuk mendukung fungsi mandibula. Menurut Oliveira (2013), pelat rekonstruksi mandibula dan sekrup sistem 2,4 merupakan alat yang paling diakui secara luas untuk merekonstruksi mandibula. Penambahan ulir pada kepala sekrup dengan locking systems (load bearing) akan menjadi anchorage pelat rekonstruksi mandibula, sehingga mengurangi gangguan terhadap suplai darah pada tulang di bawah pelat. Sistem ini akan memberikan rangka konstruksi rigid yang baik dengan stabilitas mekanis yang sangat berguna terutama pada penggunaan graf tulang.

Menurut Narra (2013), pelat titanium mandibula komersial (Stock plate) yang digunakan untuk rekonstrukasi defek mandibula sampai saat ini, didesain untuk average pasien dan disuplai sebagai pelat logam berbentuk lurus atau slightly contour dengan lubang retensi sekrup yang telah dibuat dan hanya mempunyai bentuk dan ukuran umum (generic). Sebelum digunakan, pelat rekonstruksi mandibula harus ditentukan ukuran dan bentuknya agar kontur pelat sesuai dengan bentuk lengkung mandibula (Essig dkk., 2011). Sebagian besar pembentukkan lengkung pelat rekonstrukasi pada saat ini dilakukan by hand forming technique (Boyne, 1973; Eufinger dkk., 1997; Tideman dkk., 1998;Samman dkk., 1999; Stojadinovic dkk., 1999).

Ketepatan dan lamanya pembentukan lengkung pelat by hand forming technique tergantung pada ahli bedah dan asistennya (Zhou dan Liu, 2011). Menurut Narra dkk. (2013) selama operasi ahli bedah sangat banyak menghabiskan waktu untuk membengkok- kan dan membentuk pelat agar sesuai dengan kontur tulang pasien, karena menurutSalgueiro dkk (2010), pelat rekostruksi yang beradaptasi dengan baik pada tulang sangat penting dalam mencapai stabilitas segmen-segmen, posisi spatial yang benar, dan kondisioklusi yang baik setelah reseksi. Ketidaksesuaian bentuk lengkung pelat yang dipakai untuk rekonstruksi mandibula, menurut Martola dkk. (2007) sangat berpengaruh terhadap kemungkinan terjadinya fraktur pelat dan juga dapat menyebabkan terjadinya gangguan fungsi pasca rekonstruksi mandibula (El-Fattah dkk., 2003; Singaredkk., 2004;Delacure, 2007).

Pengalaman klinis dan studi literatur telah menunjukkan bahwa stock plate yang sekarang ini digunakan untuk rekontruksi defek mandibula sering kali menjadi sasaran stress yang berlebihan sehingga menimbulkan fatique fracture (Atilgan dkk., 2010; Probst dkk., 2002). Banyak peneliti lain menunjukkan adanya komplikasi yang berkaitan dengan penggunaan pelat. Liu dalam tulisannya menunjukkan bahwa angka total komplikasi setelah rekonstruksi mandibula sebesar 14,7\% dengan komplikasi tertinggi adalah infeksi $(7,4 \%)$ (Liu, dkk., 2013). Sementara hasil penelitian Markwardt dkk., (2014) menunjukkan bahwa komplikasi plate exposure baik ekstra oral maupun intra oral 6,5 kali lebih besar dibandingkan dengan fraktur pelat, dan sedikit lebih banyak dibandingkan dengan kegoyahan sekrup atau kegoyahan seluruh pelat.

Hasil pengamatan penderita ameloblastoma di Poliklinik Bedah Mulut RSUP Dr. Sardjito pada bulan Januari 2010 sampai dengan bulan Desember 2014, menunjukkan bahwa dari 69 penderita ameloblastoma, $88,40 \%$ penderita menjalani perawatan reseksi mandibula dan 78,68\% menggunakan pelat titanium rekonstruksi mandibula, dengan angka komplikasi 24,48\% yang meliputi komplikasi plate eksposure sebanyak empat orang (33,33\%), dan dehisensi delapan orang $(66,66 \%)$. Penulisan ini bertujuan untuk mengevaluasi terjadinya komplikasi plate exposure, pascarekonstruksi mandibula dengan pelat titanium akibat reseksi mandibula penderita ameloblastoma yang dilakukan di RSUP Dr. Sardjito Yogyakarta. 
Hasil evaluasi diharapkan dapat menjadi pertimbangan untuk mengembangkan metode operasi maupun teknik desain dan fabrikasi pelat rekonstruksi.

\section{Laporan Kasus}

Seorang wanita berumur 58 tahun datang ke poliklinik Bedah Mulut RSUP Dr. Sardjito dengan keluhan adanya pelat logam yang keluar dari gusi di dalam rongga mulut dan ada luka pada kulit di rahang bawah sebelah kiri yang kadang-kadang mengeluarkan nanah. Penderita menjalani operasi pemotongan rahang karena tumor mandibula dan pemasangan pelat rekonstruksi lima tahun yang lalu di RSUP Dr. Sardjito.

Pemeriksaan Ekstra Oral (EO) menunjukkan wajah asimetris, tampak pembesaran pada sisi wajah sebelah kanan. Pada submandibula kiri tampak fistula oro kutan. Intra oral tampak pelat titanium expose pada regio 34 sampai 47.

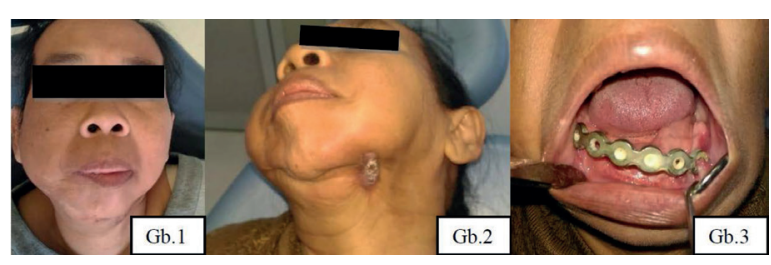

Gambar 1 dan 2. gambaran klinis pasien ekstra oral; Gambar 3. gambaran klinis intra oral

Gambar Multi CT Scan tiga Dimensi menunjukkan pelat titanium straight, 12 hole yang terpasang pada tulang mandibula yang tersisa dengan dua buah sekrup pada mandibula kiri dan dua buah sekrup pada mandibula kanan.

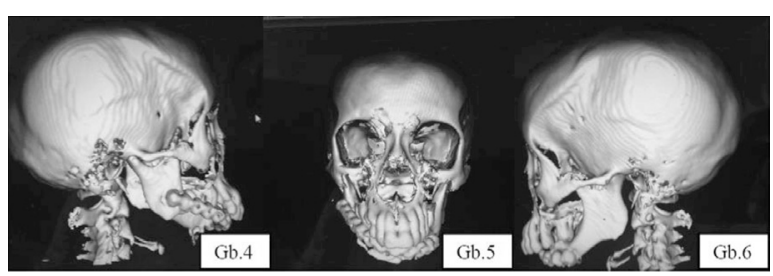

Gambar 4, 5,6: gambar Head MSCT Scan dari sisi samping kanan, depan dan sisi kiri

Penderita menjalani operasi fistulektomi dan dilakukan pelepasan pelat titanium tanpa penggantian pelat. Pelat rekonstruksi yang digunakan adalah pelat titanium non-locking system, diameter 2,4 (Stema).

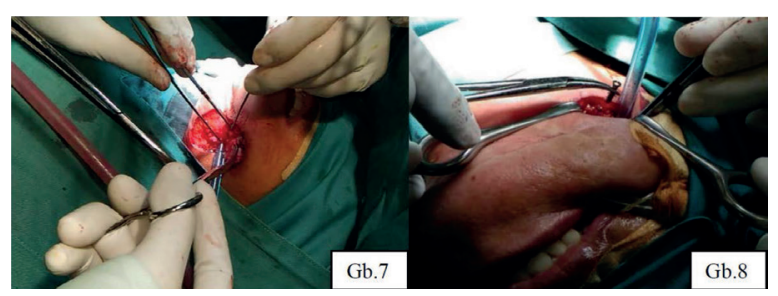

Gambar 7, 8: tindakan pengambilan screw non locking system

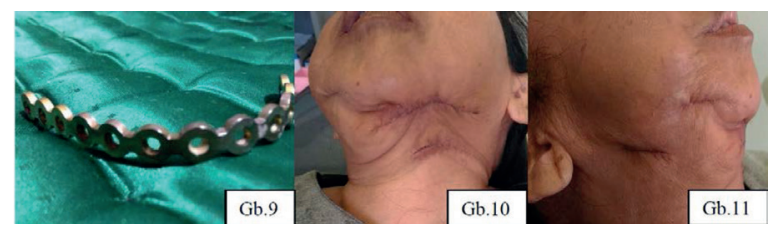

Gambar 9: pelat titanium non locking system(STEMA) setelah dilepas; Gambar 10,11: gambaran ekstra oral pasca-operasi.

\section{HASIL DAN PEMBAHASAN}

Kriteria keberhasilan rekonstruksi mandibula tidak hanya berdasarkan pulihnya kontinuitas tulang, tetapi ada beberapa sasaran utama yang harus tercapai yaitu morfologi mandibula yang mendekati normal, relasi dengan maksila yang harmonis,tinggi dan lebar tulang adekuat, kontur wajah baik, dan mendukung struktur jaringan lunak yang menutupinya serta pemulihan fungsi rahang. Akan tetapi, sampai saat ini komplikasi terkait penggunaan pelat post operasi seperti plate exposure, fraktur pelat, lepasnya sekrup dan infeksi kadang-kadang masih terjadi (Klotch dkk., 1999; Probst dkk., 2012).

Dari kasus yang dilaporkan secara radiologis (Head MSCT 3 D) tampak bahwa pelat titanium berhasil mengembalikan keutuhan mandibula, yaitu terpasangnya pelat titanium straight, 12 hole non locking system pada tulang mandibula yang tersisa dengan dua buah sekrup pada mandibula kiri dan dua buah sekrup pada mandibula kanan. Secara klinis, tampak komplikasi plate exposure intra oral dan infeksi yang ditunjukkan adanya fistula orokutan pada sisi kiri mandibula, 
sehingga wajah tampak asimetris dan relasi dengan maksila tampak tidak harmonis.

Defek yang luas mempunyai korelasi yang signifikan terhadap peningkatan angka komplikasi. Menurut Kammerer bahwa prognosis terjadinya komplikasi dehisensi pada defek yang luas secara signifikan lebih tinggi $(92 \%)$, dibanding komplikasi pada defek sedang (TUN = 6-10 gigi) sebesar $62 \%$ dan defek kecil (TUN, 5 gigi) sebesar 46\% (Kammerer dkk., 2013). Pengukuran luas defek dapat dihitung dengan tooth units (TUN) dan dari kasus yang dilaporkan menunjukkan bahwa kerusakan tulang mandibula pada pasien ini termasuk klasifikasi besar karena mencakup gigi 34 sampai 47 (11 gigi). Pendapat ini didukung oleh Arden dkk. (1999) yang menyatakan bahwa adaptasi pelat yang lebih panjang dalam tiga dimensi untuk defek yang luas lebih sulit dibandingkan pada defek yang lebih kecil. Defek yang lebih besar mempunyai dead space yang lebih besar di bawahnya, dan juga jauh lebih banyak kontak dengan jaringan parut dan jaringan lunak sehingga menyebabkan lebih sering terjadi dehisensi.

Lokasi anatomis juga berhubungan dengan besarnya angka komplikasi. Reseksi luas yang meliputi defek lateral dari kedua sisi mandibula disertai defek pada daerah sentral yang berhubungan dengan kedua sisi lateral (LCL) secara signifikan meningkatkan komplikasi dehisensi dibandingkan dengan defek tipe lain, seperti defek lateral (L), sentral lateral (CL) atau sentral (C). Dehisensi ekstra oral secara signifikan jauh lebih banyak pada defek LCL, sedangkan dehisensi intra oral banyak terjadi pada defek CL (Kammerer dkk., 2013). El Fattah dkk. (2003) dalam penelitiannya juga mendapakan insidensi dehisensi kulit dan plate exposure sebesar 11,5\% (6 dari 52 kasus) serta insidensi plate exposure lebih tinggi pada daerah korpus mandibula dibandingkan dengan regio lainnya (28,5\%).

Plate exposuredapat disebabkan karena penutupan pelat yang tidak baik atau disebabkan jaringan lunak dan penempatan pelat tidak adekuat. Pembentukan pelat rekonstruksi terutama pada defek daerah korpus, ramus dan kondilus tidak dapat dilakukan sebagaimana mestinya karena sulit untuk membentuk pelat yang cocok sebelum bagian tulang yang di reseksi dibuang seluruhnya. Metode ini meningkatkan terjadinya risiko exposure dan kegagalan rekonstruksi dengan pelat.

Menurut Andrew (1993), sebaiknya pada rekonstruksi mandibula pembentukan pelat dilakukan sebelum reseksi mandibula dan dipasang setelah reseksi.Penggunaan cetak wajah dapat digunakan sebagai panduan pembentukkan lengkung, tetapi memberikan rasa tidak nyaman dan hasil kurang akurat. Salgueiro dkk.(2010); Katsuragi Y dkk. (2010); Yamada dkk. (2010); Widiastuti; dan Pascawinata (2013); Azuma dkk., (2014) menggunakan model mandibula 3D atau model stereolitografi sebagai panduan pembentukan lengkung pelat sebelum operasi. Penggunaan model mandibula 3D dapat mencapai akurasi yang dibutuhkan karena sesuai dengan morfologi mandibula dan dapat mencegah kelelahan logam akibat faktor trial and error dan bahkan dapat mengurangi waktu operasi.

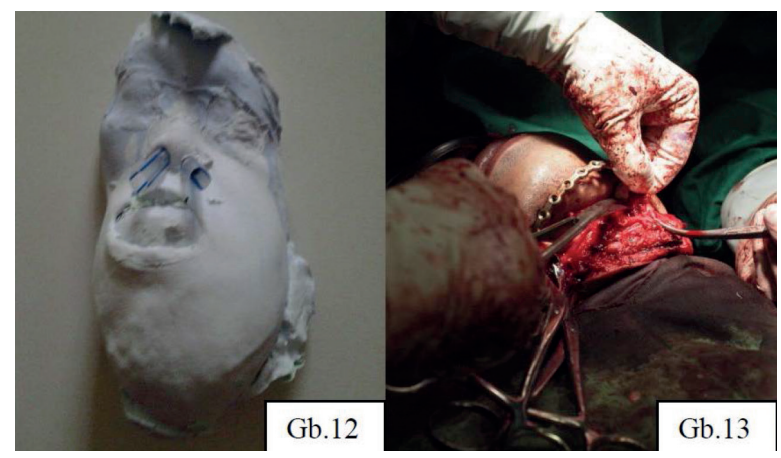

Gambar 12: cetak wajah penderita ameloblastoma sebagai panduan pembengkokan pelat rekonstruksi; Gambar 13: adaptasi pelat rekonstruksi mandibula pascareseksi mandibula durante operasi

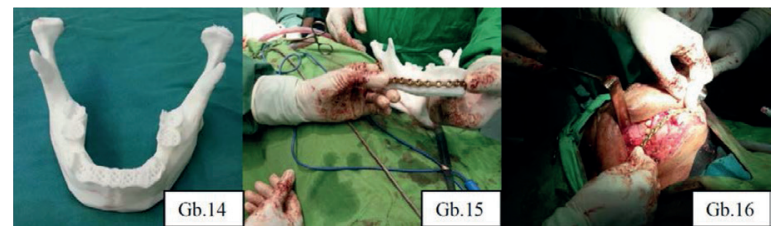

Gambar 14: model mandibula 3D sebagai panduan pembengkokan pelat pre-operasi; Gambar 15: hasil pembengkokan pelat titanium pada model mandibula 3D; Gambar 16: adaptasi pelat titanium pada mandibula setelah reseksi. 
Apabila mukosa dan atau kulit yang melekat pada tumor terpotong pada waktu tindakan operasi, maka akan mengakibatkan ketegangan pada waktu penutupan luka operasi, sehingga dapat terjadi plate exposure baik ke area intra oral maupun ekstra oral. Untuk memperkecil masalah ini, beberapa peneliti menganjurkan pelat dibengkokkan sesuai dengan aspek medial mandibula dan pembengkokan pelat dilakukan sebelum reseksi untuk mempertahankan posisi mandibula (El-Fattah dkk.,2003). Menurut Oliveira bahwa apabila kuantitas jaringan lunak kurang memadai, dapat dilakukan insisi horizontal pada periosteum, untuk menjamin kelenturan jaringan lunak. Tindakan ini akan menjamin penyembuhan yang baik (tensionfree), mengurangi rasa tidak nyaman post operasi dan mengurangi komplikasi dehisensi (Oliveira dkk., 2013).

Keliman dan Guillane (1987) juga menegaskan bahwa pada rekonstruksi mandibula, selain terjaminnya jaringan lunak yang menutup pelat, penjahitan permukaan kulit atau mukosa, dan fiksasi jaringan lunak bagian dalam terhadap pelat juga sangat penting. Hal ini disebabkan karena ada tiga peranan otototot pengunyahan pada waktu berfungsi, yaitu sebagai penggerak mandibula, balancer, dan stabilizer (DuBrull, 1988).

Pemilihan desain pelat atau titanium plate system sangat berpengaruh terhadap keberhasilan tindakan rekonstruksi mandibula karena hilangnya keutuhan tulang mandibula lebih membutuhkan sistem yang kuat (load bearing system) yang mendukung fungsi mandibula. Penggunaan pelat rekonstruksi mandibula dengan non- locking system serta profil pelat yang tebal meningkatkan terjadinya komplikasi plate exposure pada kasus ini karena tidak memberikan kerangka bangunan rigid yang sangat baik dengan stabilitas mekanis yang tinggi dibandingkan dengan pelat rekonstruksi locking system (Kirkpatrick dkk., 2003; Knott, dkk., 2007; Szypryt dan Forward, 2009; Hariani dkk., 2012; Oliveira dkk., 2013).

Untuk mengatasi komplikasi plate exposure pada kasus ini dilakukan pengambilan pelat rekonstruksi tanpa diganti pelat yang baru karena sudah terjadi proses penyembuhan jaringan lunak. Tindakan fistulektomi dilakukan untuk memperbaiki fistula orokutan pada mandibula kiri.

\section{SIMPULAN}

Adaptasi lengkung pelat titanium yang kurang sesuai merupakan salah satu penyebab utama terjadinya komplikasi plate exposure. Penggunaan model stereolitografi tiga dimensi sangat membantu keberhasilan rekonstruksi mandibula.

\section{UCAPAN TERIMAKASIH}

Ucapan terimakasih yang sebesarbesarnya ditujukan kepada Prof. Dr. drg. Widowati Siswomihardjo, M.S. yang telah memberikan dukungan dalam penulisan naskah publikasi ini serta kepada drg. Cita dan drg. Yuni yang telah membantu dalam dokumentasi penelitian.

\section{DAFTAR PUSTAKA}

Andrew, T. And Lyos, M., 1993, Mandibular Reconstruction, Feb., 18.

Arden, R.L., Rachel, J.D., Marks, S.C., Dang, K., 1999, Volume-Length Impact of Lateral Jaw Resections on Complication Rates, Arch Otolaryngol Head Neck Surg, 125, 68-72.

Asian Congress on Oral and Maxillofacial Surgeons, $10^{\text {th }}$, Bali Indonesia, 2012, "A New Paradigm and Strategic Approach in Oral and Maxillofacial Surgeons: Evaluation of Rankl and Opg Expression in Folicular and Plexiform Type Ameloblastoma", Yulvie, W., Latief B.S., Handayani, D.R., Indonesian Association of Oral and Maxillofacial Surgeons, Bandung.

Atilgan, S., Erol, B., Yardimeden, A., Yaman, F., Ucan, M.C., Gunes, N., Atalay, Y., Kose, I., 2010, "A Three Dimensional Analysis of Reconstruction Plates Used in Different Mandibular Defects", Journal of Biotechnol. \& Biotechnol. Eq., 24(2), hal. 1893-1896. 
Azuma, Masaki., et al, 2014, "Mandibular Reconstruction Using Plates Prebent to Fit rapid Prototyping 3-dimensional Printing Models Ameliorates Contour Deformity", http://www.head-facemed.com, diakses pada tanggal 30 Desember 2014.

Blackwell, E. Keith, Lacombe, V., 1999, "The Bridge Lateral Mandibular Reconstruction Plate Revisited", Archive of Otolaryngol Head Neck Surgery, 125, hal. 988-993.

Boyd, T.G., Huber, K.M., Verbist, D.E., Bumpous, J.M., Wilhelmi, B.J., 2012, "Removal of Exposed Titanium Reconstruction Plate After Mandibular Reconstruction With a Free Fibula Osteocutaneous Flap With Large Surgical Pin Cutters: A Case Report and Literature Review", AnOpen Access Journal, 12, 371-377.

Boyne, P.J., 1973,"Methods of Osseous Reconstruction of The Mandible Following Surgical Resection", Journal of Biomedical Materials Research, Vol 7, No. 195, 195-204.

Chen, T.M., Wang, H.J., Cheng, T.Y., Chang, K.c., Lin, F.H., 2000, the Rationale of Mandible Reconstruction in Advanced Oral Cancer: Alloplastic Material Versus Autogenous Vascularized Bone Graft", Materials Science and Engineering, C13, hal. 4958.

Chen, W. T., Li, J., Yang, Z.H., Wang, J. G., Zhang, B, 2006, Ameloblastoma of TheAnterior Skull Base: Three Cases Treated by Radical Resections, J. Cranio maxillofac Surg., 34:412-414.

Clement, K.S., Rassekh, C.H., Quin, F.B., 1997, "Mandibular Reconstruction", UTMB Department of Otolaryngology/ Head and Neck Surgery.

Delacure, M., 2007, "Reconstruction of The Mandible", Indian J Plast Surg. Vol. 40, Supplement, hal. S28-S34.
DuBrull, E.L., 1988, "Sicher and DuBrul's Oral Anatomi", $8^{\text {th }}$ ed., Ishiyaku Euro America, Inc., St. Louis, Tokyo, hal. 31-36.

El-Fattah, H.M.A., Zaghlol A., Emera, G., Sedera, M.A., 2003, "Immediate ReEstablishment of Mandibular Continuity After Tumor Surgery Using Reconstruction Plates", Egypt J Plast Reconstr Surg, 27(1), hal. 11-18.

Essig, H., Rana, M., Kokemuller, H., von See, C., Ruecker, M., Tavassol, F., Gelrich, N.C., 2011, "Pre-Operative Planning for Mandibular Reconstruction - A Full Digital Planning Workflow Resulting in A Patient Specific Reconstruction", Head and Nech Oncology, 3(45), hal. 1-7.

Eufinger, H., Wehmoller, M., Machtens, E., 1997, Individual Prostheses and Resection Templates for Mandibular Resection and Reconstruction, British Journal of Oral and Maxillofacial Surgery, Vol. 35, No 6, December 1997, 413-418.

Gardner, D.G., Heikinhemo, K., Shear, M., Philipsen, H.P., Coleman, H., 2005, "Ameloblastoma", In: Barnes, L., Evenson, J.W., Reichart, P., Sidransky, D., eds. World Health Organization Classification of Tumors, Pathology and Genetics of Head and Neck Tumor, Lyon: IARC Press, hal. 296-300.

Gunggum, S., Hosrogen, B., 2005, “Clinical and Radiologic Behaviour of Ameloblastoma in 4 Cases", J. Can Dent Assoc, 71:481-484.

Hariani, B., Singh, R.K., Pal, U.S., Singh, G., 2012, Locking v/s Non- Locking Reconstruction Plates in Mandibular Reconstruction, Natl J. Maxillofac. Surg, 3,159-165.

Jedrusik-Pawlowska, Magdalena., et al, 2013, "Mandibular ReconstructionBiomechanical Strength Analysis (FEM) based on A Retrospective Clinical 
Analysis of Selected Patients", Acta of Bioengineering and Biomechanics Vol. 15 No. 2.

Kammerer, P.W., Klein, M.O., Moergel, M., Gemmel, M., Draenert, G.F., 2013, Local and systemic risk factors influencing the long-term success of angular stable alloplastic reconstruction plates of the mandible, Journal of Cranio=Maxillo-Facial Surgery, XXX, 1-6.

Katsuragi Y, dkk., Kayano, S., Azakawa, S., Nagamatsu, S., Koizumi, T., Matsui, T., Onisuka, T., Yurikusa, T., Chao Huang, W,, Nakagawa, M., 2011, Mandible Reconstruction using The Calcium - Sulphate ThreeDimensional Model and Rubber Stick: A New Method, "mould technique ', for more Accurate, Efficient and Simplified Fabrication, Journal of Plastic Reconstructive $\mathcal{E}$ Aesthetic Surgery, 64, 614-622.

Keliman , R.M., and Guillane, P.J., 1987, Use of the $\mathrm{A} / \mathrm{O}$ reconstruction plate for bridging of mandibular defects, Clin. North Am., 20,519.

Kim, S.G., Jang, H.S., 2001, “Ameloblastoma: A Clinical, Radiographic, and Hispathologic Analysis of 71 Cases", Oral Surg. Oral Med. Oral Pathol. Oral Radiol Endod, 91, hal. 649-653.

Kirkpatrick, D., Gandhi, R., Van Sickles, J.E., 2003, "Infections Associated with Locking Reconstruction Plates: A Retrospective Review", Journal of Oral Maxillofacial Surgery, 61(4), 462-466.

Klotch, D.W., Gal, T.J., Gall, R.L. ,1995, "Assesment of Plate Use for Mandibular Reconstruction : Has Changing Technology Made a Difference ?"

Knott, P.D., Suh, JD., Nabili, V., Sercarz, J.A., Head, C., Abemayor, E., Blackwell, K.E, 2007, Evaluation of hardwarerelated complications in vascularized bone grafts with locking mandibular reconstruction, Arch Otolaryngol Head Neck Surg. 133(12):1302-6.

Liu, S.P., Cai, S.G., Zhang, J.G., Zhang, Y., 2013, Plate Related Complication after Mandibular Reconstruction, http / / www,ncbi,nlm.nih.gov/ pubmed/24438564, diunduh tanggal 29 Oktober 2014.

Markwardt, Jutto., et al, 2007, "Analysis of Complications after Reconstruction of Bone Defects Involving Complete Mandibular Resection Using Finite Element Modelling", http://www. karger.com/onk, onkologie 2007; 30:121-126, diakses pada tangga; 10 Januari 2015.

Martola, M., Lindqvist, C., Hanninen, H., Al-Shukun, J, 2007, "Fracture of Titanium Plates Used for Mandibular Reconstruction Folllowing Ablative Tumor Surgery". Journal Biomed Mater Res B Appl Biomater, 80(2), hal. 345-352.

Maurer, P., Eckert, A.W., Kriwalsky, M.S., Schubert, J., 2010, "Scope and Limitation of Methods of Mandibular Reconstruction: Along-term Followup", Br J Oral Maxillofac Surg, 48(2), hal.100-104.

Narra, Nathaniel et al, 2013, "Finite Element Analysis of Customizeed Reconstruction Plates for Mandibular Continuity Defect Theraphy", Journal of Biomechanics.

Oji, C., Uguru, C.C., Mgbokwere, U., Chukwuneke, F., Ugomuoh R.N., Ezike, H., 2003, “A Technique of Tongue Fixation After Total Mandibulectomy: The Oji Spatula", British Journal of Oral and Maxillofacial Surgery, 41, hal. 392-395.

Oliveira, M.T.F., et al, 2013, "Reconstruction of Mandibular Defects", http://dx.doi. org/10.5772/52104, diakses pada tanggal 5 Januari 2015, chapter 17.

Probst, F.A., Mast, G., Ermer, M., Gutwald, R., Schmelzeisen, R., Pautke, C., 2012, Matrix MANDIBLE Preformed 
Reconstruction Plates - a two-year twoinstitution experience in 71 patients, J. Oral Maxillofac. Surg, 70, hal 657666.

Rana, M., Warraich, R., Kokemuller, H., Lemound, J., Essig, H., Tavassol, F., Eckardt, A., Gellrich, N.C., 2011, "Reconstruction of Mandibular Defects -Clinical Retrospective Research Over a 10 Year Periode-", Head and Neck Oncology, 3.

Salgueiro, Martin I., 2010, "Experience with The Use of Prebent Plates for The Reconstruction of Mandibular Defects", Craniomaxillofac Trauma Reconstr. Dec 2010; 3(40: 201-208.

Samman, N., Luk, W.K., Chow, T.W., Cheung, L.K., Tideman, H., Clark, R.K.F., 1999,"Custom-made Titanium Mandibular Recosntruction Tray", Australian Dental Journal, 44(3), hal. 195-199.

Seminar Nasional Aktualisasi Sains dan IPTEK Kedokteran Gigi UNSOED II , AKSIKG - II 2013, Jurusan Kedokteran Gigi, Fakultas KedokterandanIlmu-ilmuKesehatan Universitas Jenderal Soedirman, Purwokerto, 2013, Current Aesthetic and Painless Dentistry, Widiastuti, M.G; Pascawinata, A; Purwokerto, Panitia AKSIKG -II 2013.

Singare, S., Dichen, L., Bingheng, L., Yanpu, L., Zhenyu, G., Yaxiong, L., 2004, "Design and Fabrication of Custom
Mandible Titanium Tray Based on Rapid Prototyping", Medical Engineering and Physics.

Soames, J.V., Southam, J.C., 1998,“Oral Pathology. 3rd ed. Oxford: Oxford University Press, hal. 275.

Stojadinovic, S., Eufinger H., Wehmoller, M., Machtens, E., 1999, One-step Resection and Reconstruction of The Mandible using ComputerAided Technique-Experimental and Clinical Results, Mund Kiefer Gesichtschir, Vol 3, May, S151-153.

Szypryt, P., Forward, D., 2009, The Use and Abuse of Locking Plates, Orthop. Trauma, 23, :281-290.

Tideman, H., Samman, N., Cheung, K.K., 1998, Functional Reconstruction on The Mandible: a Modified Titanium Mesh System. Int J. Oral Maxillofac. Surg. 27:339-345.

Yamada, H., Ishihama, K., Yasuda, K., Nakayama, Y.H., Okayama, M., Yamada, T., Furusawa, K., 2010, "Precontoured Mandibular Plate with Three Dimensional Model Significantly Shortened The Mandibular Reconstructions Time".

Zhou, L., Yanpu, L., 2011, Rapid Prototyping in Correction of Craniofacial Skeletal Deformities, dalam Advanced Applications of Rapid Protyping Technology in Modern Engineering, Diedit oleh Hoque Muhammad Enamul, China: InTech, hal. 119-128. 